\title{
A Rapid Extractive Spectrophotometric Method for the Determination of Tin with 6-Chloro-3-hydroxy-2-(2'-thienyl)- 4-oxo-4H-1-benzopyran
}

\author{
Ramesh Kataria $^{1}$ and Harish Kumar Sharma ${ }^{2}$ \\ ${ }^{1}$ Department of Chemistry and Centre of Advanced studies in Chemistry, Panjab University, Chandigarh 160014, India \\ ${ }^{2}$ Department of Chemistry, Kurukshetra University, Kurukshetra, Haryana 136119, India \\ Correspondence should be addressed to Ramesh Kataria; rkataria@pu.ac.in
}

Received 31 May 2014; Revised 3 July 2014; Accepted 31 July 2014; Published 14 August 2014

Academic Editor: Gerd-Uwe Flechsig

Copyright (C) 2014 R. Kataria and H. K. Sharma. This is an open access article distributed under the Creative Commons Attribution License, which permits unrestricted use, distribution, and reproduction in any medium, provided the original work is properly cited.

An extractive spectrophotometric method for the determination of the trace amounts of tin has been carried out by employing 6-chloro-3-hydroxy-2-(2'-thienyl)-4-oxo-4H-1-benzopyran (in acetone) (CHTB) for the complexation of the metal ion in $\mathrm{HCl}$ medium. The colored species thus produced is quantitatively extracted into dichloromethane and shows the maximum absorbance at $432-437 \mathrm{~nm}$. The method obeys Beer's law in the range $0.0-1.3 \mu \mathrm{g} \mathrm{mL}^{-1}$ of tin with molar absorptivity and Sandell's sensitivity of $5.81 \times 10^{4} \mathrm{~L} \mathrm{~mol}^{-1} \mathrm{~cm}^{-1}$ and $0.0020 \mu \mathrm{g} \mathrm{Sn} \mathrm{cm}{ }^{-2}$, respectively, at $435 \mathrm{~nm}$. The method is highly selective and free from the interference of a large number of elements including platinum metals. The ratio of metal to ligand in the extracted species is $1: 2$. Utilizing this method, the analysis of various synthetic and technical samples including gun metal and tin can have been carried out satisfactorily.

\section{Introduction}

Tin does not occur free in nature and is found almost exclusively as tin oxide known as cassiterite or tin stone. Tin although a toxic metal, still it is being widely employed in manufacturing important alloys [1] and as solders for the joining of electronic components. The excess use of tin in daily life as fungicides in crops, in food packaging, and as stabilizer for polyvinyl chloride may introduce the inorganic tin $\{\mathrm{Sn}(\mathrm{II})$ and $\mathrm{Sn}(\mathrm{IV})\}$ in the environment. Out of these two, Sn(II) seems to be more toxic as compared to $\mathrm{Sn}(\mathrm{IV})$ [2]. In the literature, there are numerous analytical methods for the measurement of tin which are based on sophisticated instruments [3-10]. These methods are highly sensitive but generally tedious and prone to serious interferences from other elements. In contrast spectrophotometric methods are preferred due to their simplicity and speed in routine analysis. The reported studies have shown that a large number of reagents such as methyl orange [11], benzopyran derivatives [1, 12, 13], 2-(5-nitro-2-pyrilazo)-5-[N-n-propyl$\mathrm{N}$-(3-sulfopropyl)amino-phenoyl] [14], pyrocatechol violet
[15-18], phenylfluorone [19, 20], dibromohydroxyphenylfluorone [21], arsenazo-M [22], isoamyl xanthate [23], diacetylmonoxime-p-hydroxybenzoyl-hydrazine [24], bromopyrogallol red [25], potassium ethylxanthate [26], ferron [27], and 5,7-dichloro-8-quinolinol [28] have been used for the spectrophotometric determination of tin(II,IV) content. Among these many reagents $[18,21,23,26-28]$ are nonselective as they suffer from the interference, have low sensitivity $[11,12$, $23,24,26-28]$, and some of them are time consuming, as they require time for full color development $[14,18,20]$. Some of the sensitive reagents $[16,17,21,22,25]$ are reported, but these require the use of the surfactants, plasticizer, and critical $\mathrm{pH}$ adjustment. Thus in the view of the above facts it reveals that there is still a lot of scope for working out new methods and effecting amendments in the existing ones especially because of their lower sensitivity and selectivity. Keeping in mind the scope of the reported facts, a chromone derivative 6-chloro-3hydroxy-2-(2'-thienyl)-4-oxo-4H-1-benzopyran(CHTB) has been used for complexation and spectrophotometric determination of trace amount of tin(II). The reagent 6-chloro-3hydroxy-2-(2'-thienyl)-4-oxo-4H-1-benzopyran was found 
to give a sensitive reaction with $\mathrm{Sn}$ (II). In the present communication, optimization of conditions for the quantitative extraction of $\mathrm{Sn}$ (II)-CHTB complex was worked out apart from the studies involving stoichiometry and Beer's law range determination. The interference studies for diverse ions were also carried out and the extraction of $\mathrm{Sn}$ (II)-CHTB was made free from interference of large number of metal ions by using suitable masking agents. The extraction of the $\mathrm{Sn}$ (II)-CHTB complex into dichloromethane forms the basis of the proposed method, which provides the advantages particularly in respect of sensitivity, selectivity, and color development time to the existing methods. Some synthetic and technical samples including gun metal and tin can have been analyzed for tin contents with good agreement.

\section{Experimental}

2.1. Apparatus. A model-140-02, Shimadzu with $10 \mathrm{~mm}$ matched cells was used for the routine absorbance measurements and spectral studies.

2.2. Reagents and Solutions. The standard stock solution $(250 \mathrm{~mL})$ of $\mathrm{Sn}(\mathrm{II})$ containing $1 \mathrm{mg} \mathrm{mL}^{-1}$ of the metal ion was prepared by dissolving an accurately weighed amount $(0.475 \mathrm{~g})$ of $\mathrm{SnCl}_{2} \cdot 2 \mathrm{H}_{2} \mathrm{O}$ (RANBAXY) in $20 \mathrm{~mL}$ of concentrated hydrochloric acid, diluting with deionized water up to the mark and standardized by the $\mathrm{SnO}_{2}$ method gravimetrically [29]. Lower concentration at $\mu \mathrm{g} \mathrm{mL}^{-1}$ level was prepared by suitable dilution of this solution containing $0.5 \mathrm{~mol} \mathrm{~L}^{-1}$ $\mathrm{HCl}$ final acidity. The containers of the tin solution were wrapped with carbon paper and kept in dark place. Stock solutions of other metal ions were prepared at $\mathrm{mg} \mathrm{mL}^{-1}$ level by dissolving their sodium or potassium salts in deionized water or dilute acid. They were suitably diluted to give $\mu \mathrm{g} \mathrm{mL}^{-1}$ level concentration of the metal ions.

6-Chloro-3-hydroxy-2-( $2^{\prime}$-thienyl)-4-oxo- $4 H$-1-benzopyran (CHTB; m.p. $200-202^{\circ} \mathrm{C}$ ) was synthesized by the literature method [30] and dissolved in acetone to give $0.1 \%(\mathrm{~m} / \mathrm{v})$ solution. The chemical composition of CHTB is $\mathrm{C}_{13} \mathrm{H}_{7} \mathrm{O}_{3} \mathrm{SCl}$ and its structure is given in Figure 4.

Dichloromethane (Ranbaxy) was used for extraction as such.

2.3. The Samples. Synthetic samples were prepared by mixing tin solution with solutions of various metal ions in suitable proportions so as to give the composition as shown in Table 1.

2.4. Gun Metal. A weighed sample of gun metal (0.2 g) was dissolved in $10 \mathrm{~mL}$ of concentrated hydrochloric acid and 2$4 \mathrm{~mL}$ of concentrated nitric acid on heating and the volume was made up to $100 \mathrm{~mL}$ in a volumetric flask. $10 \mathrm{ML}$ of this solution was diluted to $100 \mathrm{~mL}$ to get a working solution of low concentration. An aliquot $(0.25 \mathrm{~mL})$ of this solution was analyzed by the proposed method.

2.5. Tin Can. A weighed sample $(0.6 \mathrm{~g})$ of tin taken in a $10 \mathrm{~mL}$ beaker was heated gently with $5 \mathrm{~mL}$ of concentrated
TABLE 1: The analysis of various samples with the proposed method.

\begin{tabular}{|c|c|c|}
\hline \multicolumn{2}{|l|}{ Sample composition } & \multirow[b]{2}{*}{ Sn found ${ }^{* *}, \mu \mathrm{g}$} \\
\hline Matrix ${ }^{*}$ & Sn added, $\mu \mathrm{g}$ & \\
\hline $\mathrm{Zn}(0.02), \mathrm{Pb}(0.01), \mathrm{Cu}(0.001)^{\mathrm{a}}$ & 10.0 & $10.03 \pm 0.85$ \\
\hline $\mathrm{Cu}(0.070), \mathrm{Co}(0.014)^{\mathrm{b}}$ & 8.0 & $7.89 \pm 0.71$ \\
\hline $\mathrm{Co}(1), \mathrm{Ba}(2), \mathrm{U}(0.01), \mathrm{Mo}(0.020)^{\mathrm{c}}$ & 7.0 & $6.83 \pm 0.58$ \\
\hline $\mathrm{Cd}(2), \mathrm{Fe}(0.1), \mathrm{V}(0.1)^{\mathrm{d}}$ & 12.0 & $11.96 \pm 0.71$ \\
\hline $\operatorname{Cr}(0.1), \operatorname{Sr}(1), \operatorname{Ag}(0.5), \operatorname{Zr}(0.01)^{\mathrm{e}}$ & 12.0 & $11.99 \pm 0.62$ \\
\hline $\mathrm{Pb}(2), \mathrm{Nb}(0.1), \operatorname{Th}(0.05)^{\mathrm{f}}$ & 5.0 & $5.13 \pm 1.63$ \\
\hline $\operatorname{As}(2), \operatorname{Se}(3), \operatorname{Ti}(0.1)^{\mathrm{e}}$ & 8.0 & $7.92 \pm 0.56$ \\
\hline $\operatorname{Re}(0.01), \operatorname{Ta}(0.05), \operatorname{Bi}(1)^{g}$ & 5.0 & $5.03 \pm 0.82$ \\
\hline $\operatorname{Be}(2), \operatorname{Pt}(0.01), \operatorname{Ir}(0.01)$ & 10.0 & $9.85 \pm 0.41$ \\
\hline Gun metal & $4.9 \%^{\mathrm{h}}$ & $4.48 \% \pm 0.72$ \\
\hline Tin can & - & $0.15 \%{ }^{\mathrm{i}}$ \\
\hline \multicolumn{3}{|c|}{$\begin{array}{l}{ }^{*} \text { Amount of metal ion shown in parentheses is in mg. }{ }^{* *} \text { Average of } \\
\text { triplicate analyses; mean } \pm \% \text { RSD. }{ }^{\text {a,b }} \text { Correspond to kneiss metal and } \\
\text { argental, respectively. }{ }^{\mathrm{c}} \text { In presence of } 0.5 \mathrm{mg} \text { dithionite. }{ }^{\mathrm{d}} \mathrm{In} \text { presence of } \\
100 \mathrm{mg} \text { ascorbic acid. }{ }^{\mathrm{e}} \text { In presence of } 7 \mathrm{mg} \text { phosphate. }{ }^{\mathrm{f}} \text { In presence of } 4 \mathrm{mg} \\
\text { oxalate. }{ }^{\mathrm{g}} \text { In presence of } 100 \mathrm{mg} \text { iodide. }{ }^{\mathrm{h}} \text { Certified value. }{ }^{\mathrm{i}} \text { Confirmed by } \mathrm{SnO}_{2} \\
\text { method. }\end{array}$} \\
\hline
\end{tabular}

hydrochloric acid. The sample was dissolved completely by adding 5-10 $\mathrm{mL}$ of distilled water and heating until the volume was reduced to 2-5 mL. After cooling, the volume of the solution was made up to $25 \mathrm{~mL}$ and suitable portions of the sample solution were analyzed for tin content.

2.6. Procedure. To $1 \mathrm{~mL}$ aliquot of the sample solution containing $\leq 13 \mu \mathrm{g} \mathrm{Sn}(\mathrm{II})$ in $0.5 \mathrm{~mol} \mathrm{~L}{ }^{-1}$ hydrochloric acid, were added $1 \mathrm{~mL}$ of 6 -chloro-3-hydroxy-2-( $2^{\prime}$-thienyl)-4-oxo- $4 H$ 1-benzopyran ( $0.1 \%$ in acetone) solution and distilled water to make the aqueous volume up to $10 \mathrm{~mL}$ in a short stemmed $125 \mathrm{~mL}$ separating funnel. The contents were mixed well and equilibrated with $10 \mathrm{~mL}$ of dichloromethane for $20 \mathrm{~s}$. The two layers were allowed to separate and the yellow colored solvent layer was passed through Whatman filter paper (number 41, $9 \mathrm{~cm}$ diameter) and collected into $10 \mathrm{~mL}$ measuring flask. The absorbance of the yellow complex was measured at $435 \mathrm{~nm}$ against similarly treated reagent blank. The standard calibration curve was prepared by applying the procedure to a solution containing tin up to $13 \mu \mathrm{g}$ per $10 \mathrm{~mL}$ of the aqueous volume. The tin contents were computed from this calibration curve.

Modifications of the method for $\mathrm{V}, \mathrm{Fe}, \mathrm{Nb}, \mathrm{Zr}, \mathrm{W}, \mathrm{Mo}$, $\mathrm{Bi}$, and $\mathrm{Ti}$ : in the sample when $\mathrm{Ti}(\mathrm{IV}), \mathrm{Zr}(\mathrm{IV})$, and $\mathrm{W}(\mathrm{VI})$ were masked with sodium phosphate, Fe(III) and V(V) with ascorbic acid, $\mathrm{Bi}(\mathrm{III})$ with potassium iodide, $\mathrm{Mo}(\mathrm{VI})$ with sodium dithionite, and $\mathrm{Nb}(\mathrm{V})$ with sodium oxalate added prior to the addition of reagent and solvent. The respective amount of the masking agents used was mentioned in the effect of diverse ions.

\section{Results and Discussion}

Tin(II) reacted with 6-chloro-3-hydroxy-2-(2'-thienyl)-4oxo-4H-1-benzopyran(CHTB) in an acid medium to form 


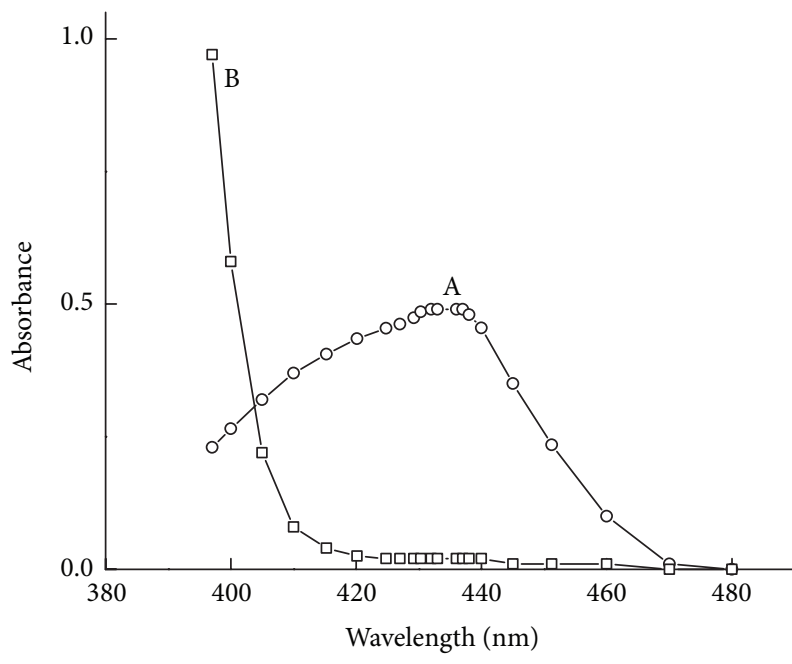

FIGURE 1: Absorption spectrum of Sn(II)-CHTB complex in dichloromethane. Curve A: $1 \mu \mathrm{g} \mathrm{Sn} / \mathrm{mL}$ measured against reagent blank; Curve B: reagent blank measured against dichloromethane.

a yellow colored species, which was quantitatively extracted into dichloromethane. The absorption spectrum of the colored $\mathrm{Sn}(\mathrm{II})$-CHTB complex in dichloromethane indicated the maximum absorbance at $432-437 \mathrm{~nm}$ in the visible region, where the reagent blank had hardly any absorbance (Figure 1). The effect of various parameters on the formation and absorbance of the complex are listed in Table 2.

The absorbance of the complex was found maximum in $\mathrm{HCl}$ medium, where as it was observed to be low in $\mathrm{H}_{2} \mathrm{SO}_{4}$, $\mathrm{CH}_{3} \mathrm{COOH}$, and $\mathrm{HClO}_{4}$. Since the $\mathrm{Sn}(\mathrm{II})-\mathrm{CHTB}$ complex showed maximum absorbance in $0.046-0.05 \mathrm{~mol} \mathrm{~L}^{-1} \mathrm{HCl}$, so $0.05 \mathrm{~mol} \mathrm{~L}^{-1} \mathrm{HCl}$ was chosen to provide suitable acidity. Portions $0.5-2.2 \mathrm{~mL}$ of $0.1 \%$ CHTB solution in acetone resulting in maximum absorbance to the complex under all the conditions were stated in Table 1 and thus $1 \mathrm{~mL}$ was considered to be sufficient for the system. Further, the complex shows maximum absorbance when an equilibration time of up to $5 \mathrm{~min}$ is kept; therefore, in order to save time, $20 \mathrm{~s}$ is considered to be the desired contact time for the extraction of the complex from the aqueous solution.

Out of the number of the solvents studied for extraction of the $\mathrm{Sn}$ (II)-CHTB complex, dichloromethane was found to be most suitable because it provides a high absorbance value and stability of the complex. The absorbance showed a downward trend in the case of dichloromethane, 1,2-dichloroethane, benzene, toluene, ethyl acetate, carbon tetrachloride, isoamyl acetate, isobutyl methyl ketone, chloroform, cyclohexane, and isoamyl alcohol. So the dichloromethane was selected for the extraction of the $\mathrm{Sn}(\mathrm{II})$-CHTB complex from the aqueous phase.

From a study of the above variables, the optimum conditions for the system have been laid down, as already stated in the procedure. The metal complex obeys Beer's law in the range $0-1.3 \mu \mathrm{g} \mathrm{Sn}(\mathrm{II}) \mathrm{mL}^{-1}$. However, according to Ringbom plot [31], the optimum range for accurate determination of tin is $0.28-1.25 \mu \mathrm{g} \mathrm{mL}^{-1}$. The molar absorptivity, specific absorptivity, and Sandell's sensitivity of the complex at $435 \mathrm{~nm}$ are
TABLE 2: Effect of various parameters on the absorbance of $\mathrm{Sn}$ (II)CHTB complex.

\begin{tabular}{lccccc}
\hline $\mathrm{HCl}^{\mathrm{a}}(\mathrm{M})$ & 0.043 & 0.044 & 0.045 & $0.046-0.060$ & 0.065 \\
Absorbance & 0.370 & 0.420 & 0.460 & 0.490 & 0.450 \\
$\mathrm{CHTB}^{\mathrm{b}}(\mathrm{mL})$ & 0.2 & 0.3 & 0.4 & $0.5-2.2$ & 2.5 \\
$\begin{array}{l}\text { Absorbance } \\
\begin{array}{l}\text { Equilibration time } \\
\text { (sec) }\end{array}\end{array}$ & 0.310 & 0.375 & 0.440 & 0.490 & 0.430 \\
Absorbance & 0.100 & 2 & 4 & $5-300$ & - \\
\hline
\end{tabular}

Conditions: (a) $\mathrm{Sn}(\mathrm{II})=10 \mu \mathrm{g} ; \mathrm{HCl}=$ variable; $\mathrm{CHTB}(0.1 \%(\mathrm{~m} / \mathrm{v})$ in acetone $)=1 \mathrm{~mL}$; aqueous volume $=$ solvent volume $=10 \mathrm{~mL}$; solvent $=$ dichloromethane; equilibration time $=20 \mathrm{~s} ; \lambda_{\max .}=435 \mathrm{~nm},(b) \mathrm{HCl}=$ $0.046-0.060 \mathrm{~mol} \mathrm{~L}^{-1}$; other conditions being the same as in (a) except for the variation in CHTB concentration; also $b=6$-chloro-3-hydroxy-2- $\left(2^{\prime}\right.$ thienyl)-4-oxo- $4 H$-1-benzopyran (CHTB), and (c) $0.1 \%$ CHTB in acetone $=$ $1 \mathrm{~mL}$; other conditions being the same as in (b) except for the variation in equilibration time.

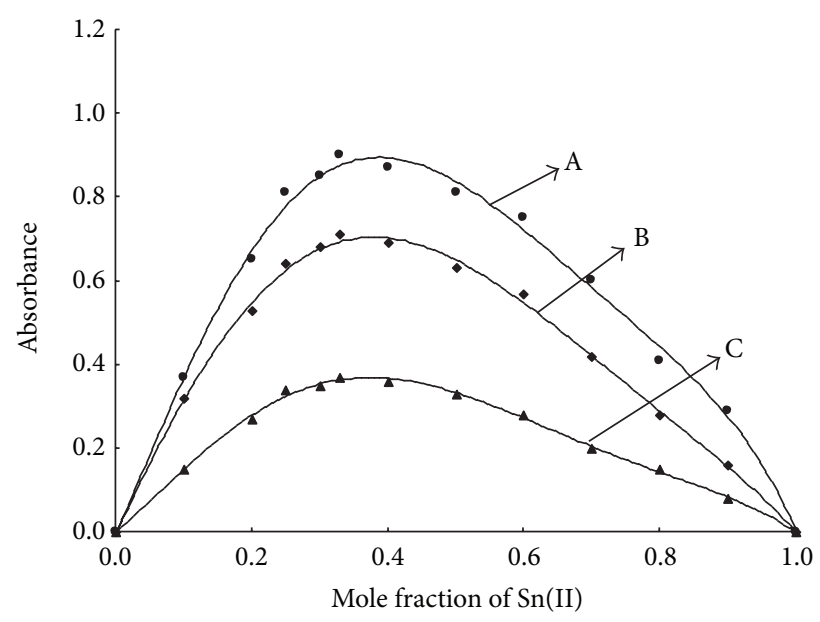

FIGURE 2: Job's method of continuous variations of $\mathrm{Sn}(\mathrm{II})$ and CHTB. Curve A:435 nm, Curve B: $410 \mathrm{~nm}$, and Curve C: $450 \mathrm{~nm}$.

$5.81 \times 10^{4} \mathrm{~L} \mathrm{~mol}^{-1} \mathrm{~cm}^{-1}, 0.489 \mathrm{~mL} \mathrm{~g}^{-1} \mathrm{~cm}^{-1}$, and $0.0020 \mu \mathrm{g}$ $\mathrm{Sn}(\mathrm{II}) \mathrm{cm}^{-2}$, respectively. The ratio of $\mathrm{Sn}(\mathrm{II})$ : $\mathrm{CHTB}$ in the extracted species is determined using their equimolar solution $\left(8.425 \times 10^{-4} \mathrm{M}\right)$ at three different wavelengths, 410,435 , $450 \mathrm{~nm}$, by Job's method (Figure 2) of continuous variations as modified by Vosburgh and Cooper for a two-phase system $[32,33]$. The sharp break in the curves indicates a metal-toligand ratio of $1: 2$ stoichiometry in the extracted species. This is further supported by the mole ratio method (Figure 3) [34] by taking the concentration of $\mathrm{Sn}$ (II) as $4.218 \times 10^{-4} \mathrm{M}$ and measuring the absorbance again at three wavelengths, 410 , $435,450 \mathrm{~nm}$. The most probable structure of the Sn-CHTB complex is given as shown in Figure 5.

3.1. Effect of Diverse Ions. Under optimum conditions of the procedure, the effect of different anions and cations has been studied on the absorbance of the Sn(II)-CHTB complex. The amount of diverse ions which caused a $\leq 1 \%$ error in the absorbance was taken as the tolerance limit. The tolerance limit of foreign ions tested is given in Table 3 . The 


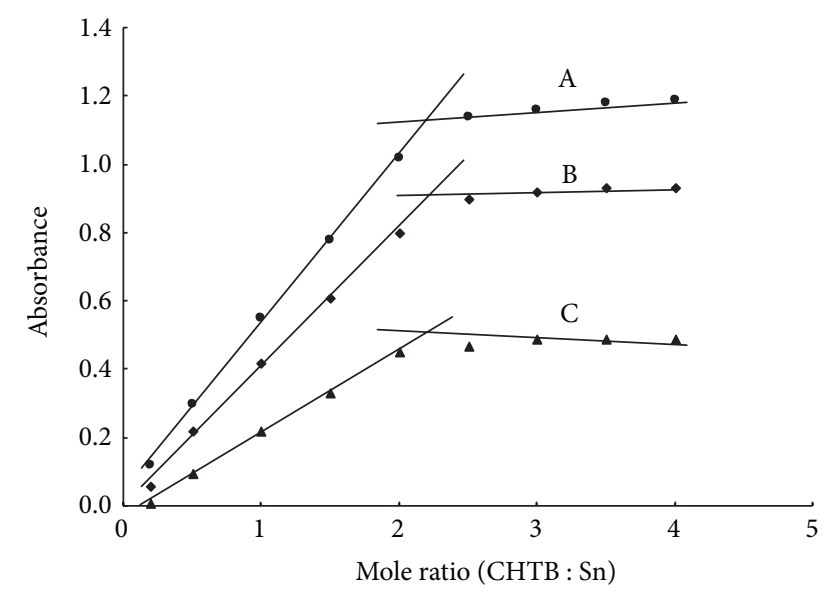

Figure 3: Mole ratio method of CHTB and Sn(II). Curve A:435 nm, Curve B: $410 \mathrm{~nm}$, and Curve C:450 nm.<smiles>O=c1c(O)c(-c2cccs2)oc2ccc(Cl)cc12</smiles>

FIGURE 4: Chemical Structure of CHTB.

reported anions and cations did not influence the absorbance of the Sn(II)-CHTB complex. However, fluoride interfered seriously even in traces. The amount of sodium or potassium salts of the various anions were taken in mg while glycerol and $\mathrm{H}_{2} \mathrm{O}_{2}(30 \%, \mathrm{~m} / \mathrm{v})$ were taken in $\mathrm{mL}$.

Among the study of cations it was found that cations like $\mathrm{Fe}(\mathrm{III}), \mathrm{Zr}(\mathrm{IV}), \mathrm{Nb}(\mathrm{V}), \mathrm{V}(\mathrm{V}), \mathrm{Mo}(\mathrm{VI}), \mathrm{W}(\mathrm{VI})$, and $\mathrm{Ti}(\mathrm{IV})$ did influence the absorbance of the Sn(II)-CHTB complex. However the interference of these metals could be prevented by making use of suitable masking agents, that is, for $1 \mathrm{mg}$ of $\mathrm{Fe}(\mathrm{III}), 100 \mathrm{mg}$ ascorbic acid; for $1 \mathrm{mg}$ of $\mathrm{Nb}(\mathrm{V}), 4 \mathrm{mg}$ sodium oxalate; for $1 \mathrm{mg}$ of $\mathrm{V}(\mathrm{V}), 100 \mathrm{mg}$ ascorbic acid; for $0.1 \mathrm{mg}$ of $\mathrm{Mo}(\mathrm{VI}), 5 \mathrm{mg}$ of sodium dithionite; for $1 \mathrm{mg}$ of $\mathrm{W}(\mathrm{VI})$, $7 \mathrm{mg}$ sodium phosphate; for $1.5 \mathrm{mg} \mathrm{Zr}(\mathrm{IV}), 7 \mathrm{mg}$ sodium phosphate; for $0.3 \mathrm{mg}$ of $\mathrm{Ti}(\mathrm{IV}), 7 \mathrm{mg}$ sodium phosphate; and for $5 \mathrm{mg}$ of $\mathrm{Bi}(\mathrm{III}), 100 \mathrm{mg}$ iodide added prior to the addition of CHTB in $10 \mathrm{~mL}$ aqueous volume under optimum condition of the procedure.

\section{Conclusion}

For the determination of microamounts of tin, the proposed method is simple, rapid, sensitive, and selective and free from the interference of a large number of metal ions. The wide applicability of the method is tested by the analysis of several synthetic samples, tin can, and gun metal sample with

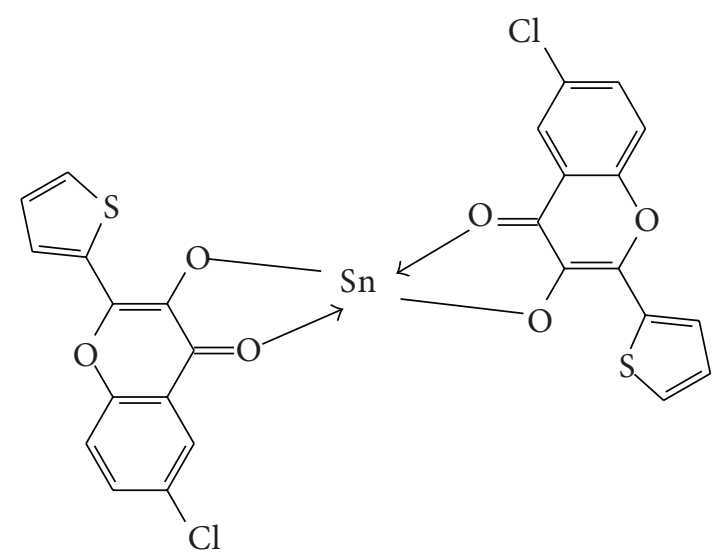

FIgure 5: Chemical Structure of Sn(II)-CHTB complex.

TABLE 3: Tolerance limit of different ions in the determination of $10 \mu \mathrm{g}$ of $\mathrm{Sn}(\mathrm{II})$.

\begin{tabular}{|c|c|}
\hline Ions & $\begin{array}{c}\text { Tolerance limit } \\
\text { (concentration } \mathrm{mg} / 10 \mathrm{~mL} \text { ) }\end{array}$ \\
\hline $\begin{array}{l}\text { Thiourea, sulphite, ascorbic acid, } \\
\text { and iodide }\end{array}$ & 100.0 \\
\hline Sulphate, nitrate & 80.0 \\
\hline Bromide, sulfosalicylic acid & 75.0 \\
\hline Chloride, tartrate & 50.0 \\
\hline Acetate & 40.0 \\
\hline Carbonate, citrate & 20.0 \\
\hline Thiocyanate & 10.0 \\
\hline Phosphate & 7.0 \\
\hline Dithionite & 5.0 \\
\hline Oxalate & 4.0 \\
\hline EDTA “disodium salt" & 2.0 \\
\hline Glycerol & $1.0^{\mathrm{a}}$ \\
\hline $\mathrm{H}_{2} \mathrm{O}_{2}(30 \%, \mathrm{~m} / \mathrm{v})$ & $0.5^{\mathrm{a}}$ \\
\hline $\mathrm{Zn}(\mathrm{II}), \mathrm{Pb}(\mathrm{II})$, and $\mathrm{Se}(\mathrm{II})$ & 10.0 \\
\hline $\mathrm{Cd}(\mathrm{II})$ & 8.0 \\
\hline $\mathrm{Ba}(\mathrm{II}), \mathrm{Ni}(\mathrm{II}), \mathrm{Co}(\mathrm{II})$, and $\mathrm{Hg}(\mathrm{II})$ & 5.0 \\
\hline $\begin{array}{l}\mathrm{Be}(\mathrm{II}), \mathrm{Ce}(\mathrm{IV}), \mathrm{As}(\mathrm{II}), \mathrm{Mg}(\mathrm{II}) \\
\mathrm{Mn}(\mathrm{II}), \mathrm{Sr}(\mathrm{II}), \mathrm{Al}(\mathrm{III}), \text { and } \mathrm{Os}(\mathrm{VIII})\end{array}$ & 3.0 \\
\hline $\mathrm{Ag}(\mathrm{I}), \mathrm{Cu}(\mathrm{II})$ & 2.0 \\
\hline $\mathrm{U}(\mathrm{VI})$ & 1.0 \\
\hline $\mathrm{Ta}(\mathrm{V})$ & 0.7 \\
\hline $\mathrm{Cr}(\mathrm{VI})$ & 0.5 \\
\hline $\operatorname{Th}(\mathrm{IV})$ & 0.3 \\
\hline $\mathrm{Ru}(\mathrm{III}), \mathrm{Ir}(\mathrm{III})$ & 0.1 \\
\hline
\end{tabular}

${ }^{a}$ Value given in $\mathrm{mL}$.

satisfactory results. The high reproducibility of the method is tested by performing several sets of experiments while keeping the same amount of tin metal ions in each set; the relative standard deviation of the method is $0.98 \%$. 


\section{Conflict of Interests}

The authors declare that there is no conflict of interests regarding the publication of this paper.

\section{Acknowledgments}

The authors' sincere thanks are due to Kurukshetra University, Kurukshetra, and Panjab University, Chandigarh, for providing the necessary facilities.

\section{References}

[1] R. Kataria, H. K. Sharma, N. Agnihotri, and J. R. Mehta, "2-(2' Furyl)-3-hydroxy-4-oxo-4H-1-benzopyran as a highly selective and sensitive reagent for spectrophotometric determination of tin(II)," Proceedings of the National Academy of Sciences of India, vol. 78, pp. 31-35, 2008.

[2] T. Madrakian, A. Afkhami, R. Moein, and M. Bahram, "Simultaneous spectrophotometric determination of $\mathrm{Sn}$ (II) and $\mathrm{Sn}(\mathrm{IV})$ by mean centering of ratio kinetic profiles and partial least squares methods," Talanta, vol. 72, no. 5, pp. 1847-1852, 2007.

[3] C. Prior and G. S. Walker, "The use of the bismuth film electrode for the anodic stripping voltammetric determination of tin," Electroanalysis, vol. 18, no. 8, pp. 823-829, 2006.

[4] Y. Mino, "Determination of tin in canned foods by X-ray fluorescence spectrometry," Journal of Health Science, vol. 52, no. 1, pp. 67-72, 2006.

[5] J.-B. Liu and Y.-Z. Wu, "Rapid determination of tin in ore by atomic emission spectrometry," Yejin Fenxi, vol. 33, no. 3, pp. 65-68, 2013.

[6] Y. Lin, "Determination of tin in canned food with hydrideatomic fluorescence spectrometry," Fenxi Ceshi Jishu Yu Yigi, vol. 19, pp. 149-152, 2013.

[7] Y. Yu, Z.-Y. He, Z.-C. Mao et al., "Determination of tin in by spectral lines with different sensitivity of alternating current arc emission spectroscopy," Yankuang Ceshi, vol. 32, pp. 44-47, 2013.

[8] L. Pruša, J. Dědina, and J. Kratzer, "Ultratrace determination of tin by hydride generation in-atomizer trapping atomic absorption spectrometry," Analytica Chimica Acta, vol. 804, pp. 50-58, 2013.

[9] S. V. de Azevedo, F. R. Moreira, and R. C. Campos, "Direct determination of tin in whole blood and urine by GF AAS," Clinical Biochemistry, vol. 46, no. 1-2, pp. 123-127, 2013.

[10] I. Trandafir, V. Nour, and M. E. Ionica, "Determination of tin in canned foods by inductively coupled plasma-mass spectrometry," Polish Journal of Environmental Studies, vol. 21, no. 3, pp. 749-754, 2012.

[11] X.-L. Wang, P. Zhang, and Y. Chen, "Spectrophotometric determination of stannum in copper alloy based on fading reaction of methyl orange," Yejin Fenxi, vol. 32, no. 12, pp. 73-75, 2012.

[12] R. Kataria and H. K. Sharma, "3-Hydroxy-2-[1'-phenyl-3' ( $4^{\prime \prime}$-methoxyphenyl)- $4^{\prime}$-pyrazoyl]-4-oxo- $4 \mathrm{H}$-1-benzopyran as a spectrophotometric reagent for the micro-determination of tin," Journal of the Indian Chemical Society, vol. 89, no. 1, pp. 121-126, 2012.

[13] R. Kataria and H. K. Sharma, "An extractive spectrophotometric determination of tin as $\mathrm{Sn}$ (II)-6-chloro-3-hydroxy-7-methyl2-(4'-methoxyphenyl)-4-oxo-4H-1-benzopyran complex into dichloromethane," Eurasian Journal of Analytical Chemistry, vol. 6, no. 3, pp. 140-149, 2011.

[14] B. Chen, Q. Zhang, H. Minami, M. Uto, and S. Inoue, "Spectrophotometric determination of tin in steels with 2-(5nitro-2-pyridylazo)-5-[N-n-propyl-N-(3-sulfopropyl)amino] phenol," Analytical Letters, vol. 33, no. 14, pp. 2951-2961, 2000.

[15] J.-H. Tang, L.-H. Cheng, and X.-M. Wu, "Pyrocatechol violetCPB spctrophotometric Determination of tin in copper alloys," Guangpu Shiyanshi, vol. 30, pp. 1925-1928, 2013.

[16] M. Abbasi-Tarighat, "Kinetic-spctrophotometric Determination of tin species using feed-forward neural network and radial basis function network in water and juices of canned fruits," Analytical Chemistry, vol. 12, pp. 256-263, 2013.

[17] T. Madrakian and F. Ghazizadeh, "Micelle-mediated extraction and determination of tin in soft drink and water samples," Journal of the Brazilian Chemical Society, vol. 20, no. 8, pp. 15351540, 2009.

[18] A. C. S. Costa, L. S. G. Teixeira, and S. L. C. Ferreira, "Spectrophotometric determination of tin in copper-based alloys using pyrocatechol violet," Talanta, vol. 42, no. 12, pp. 1973-1978, 1995.

[19] P. Huang, "Spectrophotometric determination of tin in antimony materials by using phenylflurone," Hunan Youse Jinshu, vol. 29, pp. 68-79, 2013.

[20] D.-X. Wang, F. Chen, and Z.-F. Liu, "Spectrophotometric determination of tin in flot glass," The American Ceramic Society Bulletin, vol. 84, no. 12, pp. 9401-9404, 2005.

[21] H. Yan, "Spectrophotometric determination of tin in steel with dibromo-hydroxyphenylfluorone," Yejin Fenxi, vol. 23, no. 6, pp. 45-46, 2003.

[22] C. Cai, Z. Zhou, S. Chen, and Y. Fang, "Research progress of tannery wastewater treatment," Applied Mechanics and Materials, vol. 361-363, pp. 666-669, 2013.

[23] S. P. Arya, S. C. Bhatia, A. Bansal, and M. Mahajan, "Isoamyl xanthate as a sensitive reagent for the spectrophotometric determination of tin," Journal of the Indian Chemical Society, vol. 79, no. 4, pp. 359-360, 2002.

[24] A. Varghese and A. M. A. Khadar, "Highly selective derivative spectrophotometric determination of tin (II) in alloy samples in the presence of cetylpyridinium chloride," Acta Chimica Slovenica, vol. 53, no. 3, pp. 374-380, 2006.

[25] X. Huang, W. Zhang, S. Han, and X. Wang, "Determination of tin in canned foods by UV/visible spectrophotometric technique using mixed surfactants," Talanta, vol. 44, no. 5, pp. 817-822, 1997.

[26] S. P. Arya and A. Bansal, "Rapid and selective method for the spectrophotometric determination of tin using potassium ethylxanthate," Mikrochimica Acta, vol. 116, no. 1-3, pp. 63-71, 1994.

[27] S. P. Arya, S. C. Bhatia, and A. Bansal, "Extractive-spectrophotometric determination of tin as Sn(II)-ferron complex," Fresenius' Journal of Analytical Chemistry, vol. 345, no. 11, pp. 679682, 1993.

[28] A. M. Gutierrez, M. V. Laorden, A. Sanz-Medel, and J. L. Nieto, "Spectrophotometric determination of tin(IV) by extraction of the ternary tin/iodide/5,7-dichloro-8-quinolinol complex," Analytica Chimica Acta, vol. 184, no. C, pp. 317-322, 1986.

[29] G. H. Jeffery, J. Bassett, J. Mendham, and R. C. Denny, Vogels Textbook of Quantitative Chemical Analysis? Addison Wesley Longman, Singapore, 5th edition, 1989. 
[30] S. C. Gupta, N. S. Yadev, and S. N. Dhawan, "Synthesis of 2, 3 diaryl 8 methyl 2, 3, 4, 10 tetrahydropyrano 3, 2 b, 1 benzopyran 10 ones photoisomerization of styrylchromones," Indian Journal Of Chemistry Section B: Organic Chemistry Including Medicinal Chemistry, vol. 30, no. 2, pp. 790-792, 1991.

[31] A. Ringbom, "Über die Genauigkeit der colorimetrischen Analysenmethoden I," Fresenius Journal of Analytical Chemistry, vol. 115, no. 9-10, pp. 332-343, 1938.

[32] P. Job, "Formation and stability of inorganic complexes in solution," Annali di Chimica, vol. 9, pp. 113-203, 1928.

[33] W. C. Vosburgh and G. R. Cooper, "Complex ions. I. The identification of complex ions in solution by spectrophotometric measurements," The Journal of the American Chemical Society, vol. 63, no. 2, pp. 437-442, 1941.

[34] J. H. Yoe and A. L. Jones, "Colorimetric determination of iron with disodium-1,2-dihydroxybenzene-3,5-disulfonate," Industrial \& Engineering Chemistry Analytical Edition, vol. 16, no. 2, pp. 111-115, 1944. 

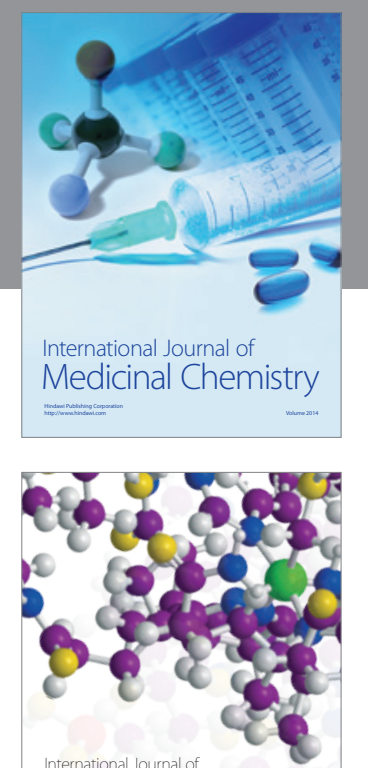

\section{Carbohydrate} Chemistry

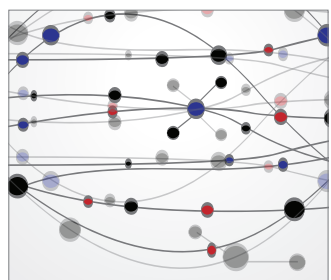

The Scientific World Journal
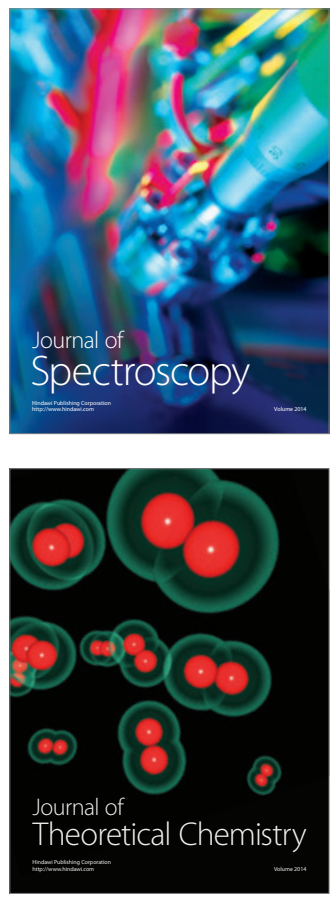
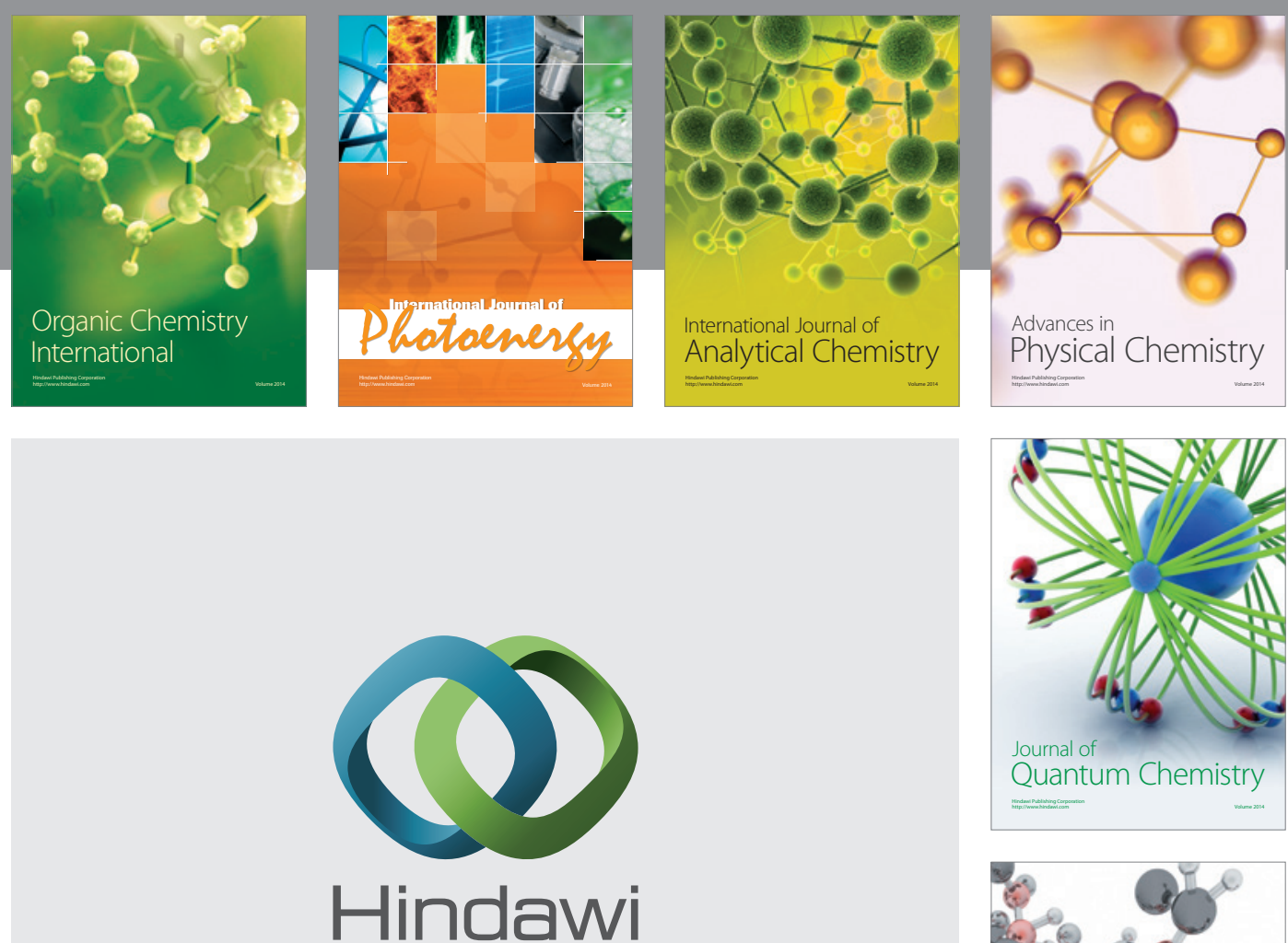

Submit your manuscripts at

http://www.hindawi.com

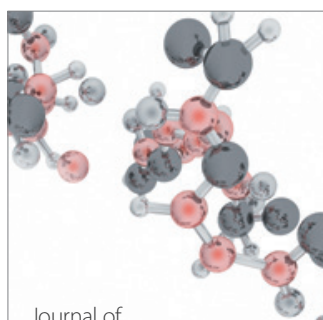

Analytical Methods

in Chemistry

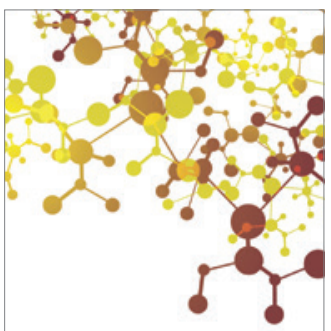

Journal of

Applied Chemistry

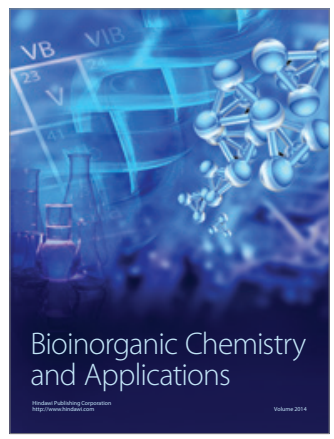

Inorganic Chemistry
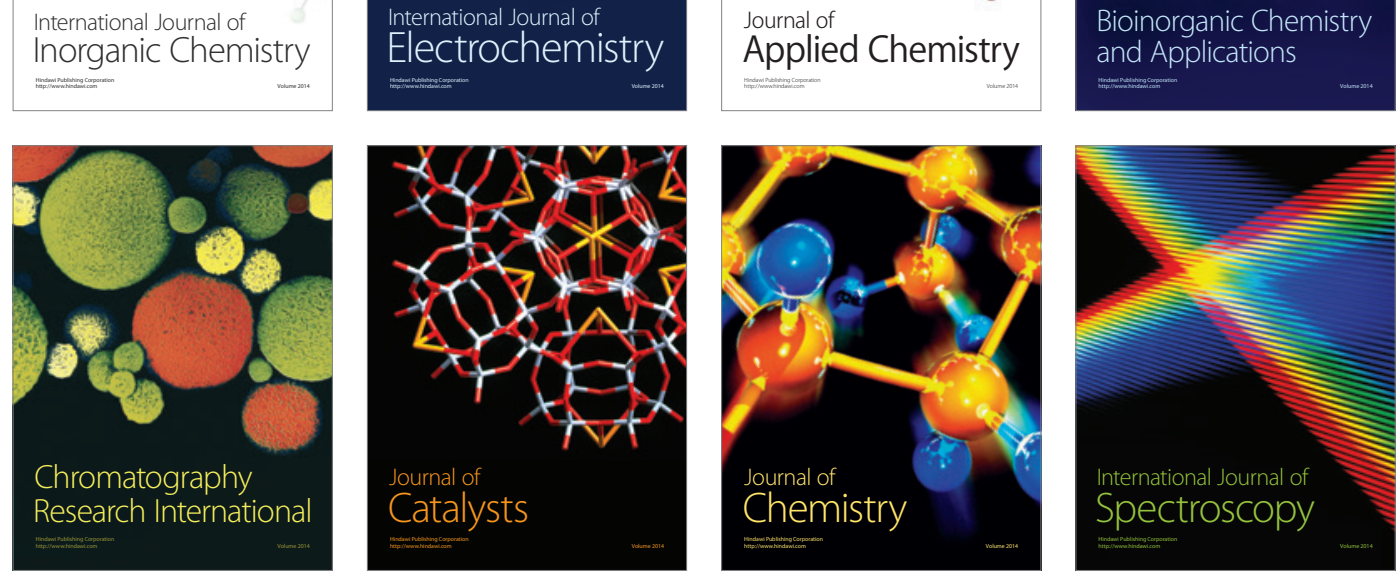